\title{
'N EKoteologiese besinNing OOR Die ChristeliK-etiese IMPLIKASIES VAN STAMSELNAVORSING EN -TERAPIE
}

\author{
Authors: \\ Stephan Hoffman ${ }^{1,2}$ \\ Johan Buitendag ${ }^{2}$ \\ Affiliations: \\ ${ }^{1}$ Department of Systematic \\ Theology and Christian \\ Ethics, University of \\ Pretoria, South Africa \\ ${ }^{2}$ Department of Dogmatics \\ and Christian Ethics, \\ University of Pretoria, \\ South Africa \\ Correspondence to: \\ Stephan Hoffman \\ email:
}

hoffmanstephan@yahoo.com

Postal address:

PO Box 8, Hartswater 8570, South Africa

Keywords:

Anthropology;

Christian ethics

ecotheology, eco-ethics;

existentialism

Dates:

Received: 24 Aug. 2009

Accepted: 29 Jan. 2010

Published: 16 July 2010

How to cite this article:

Hoffman, S. \&

Buitendag, J., 2010, "n

Ekoteologiese besinning

oor die Christelik -

etiese implikasies van

stamselnavorsing en

-terapie', HTS Teologiese

Studies/Theological Studies

66(1), Art. \#333, 10 pages.

DOI: $10.4102 /$ hts.v66i1.333

This article is available

at:

http://www.hts.org.za

Note:

Hierdie artikel is 'n

verwerking van 'n deel

van die proefskrif van

Stephan Hoffman, onder

leiding van prof. dr Johan

Buitendag, Hoof van die

Departement Dogmatiek

en Christelike Etiek

Universiteit van Pretoria,

ter gedeeltelike vervulling

van die DD-graadvereistes

aan dieselfde universiteit.

(C) 2010. The Authors.

Licensee: OpenJournals

Publishing. This work

is licensed under the

Creative Commons

Attribution License.

\section{ABSTRACT}

An Eco theological reflection on Christian-ethical implications of stem cell research and therapy

The new biotechnological context in which in vitro fertilisation, the human genome project, and stem cell research have become realities, confronts both society and theology with unique challenges. These realities compel us to revisit ethical questions regarding human life. The main aim of this study is to contribute to the transversal debate about Christian ethics, natural sciences and biotechnological development, from a post-foundational perspective. The research results do not aim to lay down ethical rules as absolute truths, but rather to reflect on different viewpoints, values, characteristics, virtues, moral narratives and perspectives with regard to these complex ethical dilemmas. The broadening of moral narratives, and the revaluing of relational Christiananthropological perspectives, are being presented as an alternative to the strict monolithically orientated ideas of truth, objectivity and reason.

\section{INLEIDING}

James Thomson en sy medewerkers het in November 1998 die isolasie van menslike pluripotente stamselle aangekondig, nadat dierlike stamselle reeds in 1995 suksesvol geïsoleer is (Thomson et al. 1998:1145-1147). Benewens die isolasie van menslike embrioniese stamselle (HES), het die isolasie van menslike embrioniese kernselle (HEG) boonop ook in 1998 ' $n$ werklikheid geword (Holland, Lebacqz \& Zolloth 2001:3-11).

Embrioniese stamselle toon dieselfde eienskappe as volwasse selle, behalwe dat hierdie selle gedurende die vroeë ontwikkeling van die embrio gevorm word, en nog nie in daardie stadium as ' $n$ spesifieke soort sel gespesialiseer (of gedifferensieer) het nie. Met embrioniese stamselnavorsing word die manlike sperm en die vroulike eiersel kunsmatig versmelt om 'n sigoot ('n enkele sel/embrio) te vorm. Stamselle word dan later uit hierdie embrio 'getap', waarna die oortollige embrio's vernietig of vir latere gebruik gevries word. Die doel van stamselnavorsing is om hierdie stamselle uit die embrio te onttrek, en dit in ' $\mathrm{n}$ medium te plaas waar dit weens molekulêre stimulasie moontlik in die verlangde soort weefsel of selfs orgaan kan ontwikkel.

Stamselle is die basisselle waaruit al die verskillende selle van die liggaam ontwikkel. Huidige stamselnavorsing wat bepaald op bevrugte menslike embrio's gedoen word en embrioniese stamselle vereis, is ' $n$ groot strydpunt (Atala et al. 2008:1-16).

Kloning maak deel uit van die proses, omdat die ontvanger van hierdie gekweekte weefsel ook die skenker moet wees ten einde genetiese ooreenkoms te verseker, en verwerping van die weefsel te voorkom. Die stryd hieroor is net werklik verstaanbaar indien ' $n$ mens begryp wat stamselle is, en wat stamselnavorsing behels.

Etiese vrae oor hierdie biotegnologiese ontwikkeling hou in 'n mate verband met die vrae oor aborsie en genadedood (eutanasie), maar die etiese dilemma oor die benutting van die menslike embrio in isolasie maak die saak selfs meer kompleks. Christelik-etiese vrae wat na vore kom, handel oor die begin van menslike lewe, respek vir lewe en dood, en die soeke na die verhouding tussen menslike verantwoordelikheid en Goddelike beskikking (Harris 2004:114-115). Die vraag na die verhouding tussen God, mens en omgewing lê ten grondslag hieraan.

Die tradisioneel Christelik-etiese verwysingsraamwerke slaag nie tans daarin om die unieke vrae oor hierdie nuwe ontwikkeling behoorlik te verreken nie. 'n Fundamentalistiese Skrifbeskouing, ' $n$ monolitiese waarheidsbegrip, en ' $n$ atomistiese wêreldbeskouing bied nie voldoende antwoorde op die komplekse vrae oor etiese besluitneming nie. Daar is dus ' $n$ behoefte aan nuwe beskouinge in hierdie verband: 'Etiek profileer immers die horison waarbinne die Christen tot ' $n$ bepaalde verantwoordelikheid kan kom' (Buitendag 2005:2).

\section{STAMSELLE}

Die ontdekking van stamselle het uit ontledings van 'n soort kanker, naamlik ' $\mathrm{n}$ teratokarsinoom, gespruit. In 1964 het navorsers ontdek dat ' $n$ enkele sel van die teratokarsinoom geïsoleer kan word, en ongedifferensieerd kan bly in ' $n$ kweekmedium. Hierdie tipe stamselle het as EK-selle (embrioniese karsinoomselle) bekend geword. Navorsers het bevind dat ES-selle (primordiale embrioniese stamselle) gestimuleer kan word om verskeie seltipes te produseer. Selle wat só in ' $n$ laboratorium groei, word ' $n$ stamselkweking of stamselkultuur genoem. Twee onafhanklike navorsingsgroepe het eers in 1981 die eerste keer ES-selle uit muisembrio's verkry (Andrews et al. 1984:147-162). 
Stamselle is die hoofmoederselle wat in alle multisellulêre organismes voorkom, en het twee belangrike eienskappe wat hulle van ander selle in die liggaam onderskei:

- Stamselle is ongedifferensieerde selle wat in sekere fisiologiese of eksperimentele omstandighede gestimuleer kan word om in ander gespesialiseerde seltipes, byvoorbeeld die hartspierweefsel, te ontwikkel.

- Stamselle kan vanself herstel of hulself herskep, en kan dus op hul eie verdeel, nóg stamselle produseer, en weefsel vernuwe. Gewone weefseltipes, soos spier-, bloed- of senuweeselle, beskik nie oor hierdie vermoë nie (Kochar 2004:1).

Wat bogenoemde eerste eienskap van stamselle betref, naamlik 'onbepaalde potensie' of die vermoë om uit enige volwasse seltipe te differensieer, is verdere klassifikasie nodig:

- Totipotente stamselle, byvoorbeeld 'n bevrugte eiersel, kan in alle seltipes - sowel embrionies as ekstraembrionies (wat die embrioniese membrane insluit) - verdeel. Die eerste paar verdelings van die bevrugte eiersel is ook totipotent (Schöler 2007:27).

- Pluripotente stamselle is die nasate van die totipotente selle, en kan in selle van al drie primitiewe kiemlae van die blastosist (drie tot vyf dae oue embrio) ontwikkel, byvoorbeeld gekweekte MES (menslike embrioniese stamselle).

- Multipotente stamselle kan in verskeie tipes aanverwante weefsel ontwikkel, byvoorbeeld hematopoiëtiese stamselle wat in gestreeptespier-, hartspier-, lewerweefsel- en al die soorte bloedselle kan ontwikkel.

- Oligopotente stamselle kan net in 'n paar tipes weefsel ontwikkel, byvoorbeeld miëloïede voorloperstamselle wat in vyf tipes bloedselle kan ontwikkel. Kwadipotente, tripotente, bipotente en unipotente stamselle kan onderskeidelik in vier, drie, twee en een soort weefsel ontwikkel, maar kan hulself steeds herskep of herstel. In teenstelling met stamselle, word gewone weefselselle soms as nullipotente selle geklassifiseer. Hierdie selle, byvoorbeeld rooibloedselle, het reeds ten volle gedifferensieer, en kan geen verdere seldeling ondergaan nie (Schöler 2007:28).

Rao, Cai en Weiss (2004:585-598) voer aan dat alle stamselle, ongeag hul oorsprong, bepaalde gemeenskaplike eienskappe het. Hierdie groep wetenskaplikes het 'n studie op 'stamlose' gene (stemless genes) uitgevoer, en tot die gevolgtrekking gekom dat alle stamselle ' $n$ reeks gene bevat wat as universele merkers kan dien. Hierdie kode vir proteïene speel 'n rol in stamselle se selfvernuwings- en selfdifferensiële eienskappe. Dit bepaal ook sommige verskille in onderskeie selpopulasies se geenuiting.

Die bepaalde faktore en omstandighede wat stamselle in staat stel om ongedifferensieerd te bly is ' $n$ kernbelangstellingsveld in die wetenskap. Daar is baie onbeantwoorde vrae oor hierdie eksterne stimuli, byvoorbeeld of die interne en eksterne stimuli eenders is vir alle stamselle. Antwoorde op hierdie vrae is nodig om selterapie verder te ontwikkel (Panagiotis 2004:81-83; DeLeon \& Davidson 2007:191-212)

\section{Terapeutiese kloning}

Die opspraakwekkende kloning van Dolly die skaap op 05 Julie 1996 het deur middel van 'somatiese selkernoordrag' plaasgevind. Sedertdien is minstens sewe ander dierspesies suksesvol met behulp van hierdie proses gekloon (Baier et al. 2004:396-404; Zheng et al. 2004:925-940). 'n Aangepaste weergawe van hierdie proses word tans vir mense ondersoek (Kochar 2004:9)

Somatiese selkernoordrag behels die onttrekking van die kern van 'n eiersel. Dié kern bevat natuurlik die genetiese materiaal (deoksiribonukleïensuur/DNS) van 'n organisme. Daarna volg die onttrekking van die kern van 'n somatiese sel (enige liggaamsel behalwe 'n sperm- of eiersel). In die praktyk sou hierdie somatiese sel van die pasiënt geoes word wat die terapie moet ontvang. Die kern van die somatiese sel word dan in die eiersel ingeplant. Die eiersel bevat dus nou die genetiese materiaal én instruksies van die skenker. Die sel word gestimuleer om te differensieer, wat ' $n$ blastosist laat vorm. Die binneste selmassa word geïsoleer, en 'n sellyn word gekweek soos dit hier bo beskryf word. Hierdie ES-selle word teruggeplaas in die pasiënt, waar dit by die beskadigde weefsel moet integreer om herstel in die hand te werk. Die grootste voordele van hierdie proses is dat die gekweekte selle ook pluripotent is, en dus in enige orgaan of weefsel kan differensieer. Dié proses skakel boonop immuniteitsverwerping uit, omdat die pasiënt se eie genetiese materiaal gebruik word. Dit bring ook ' $\mathrm{n}$ beduidend korter wagtydperk vir geskikte organe vir oorplanting mee. Met behulp van dié metode kan wetenskaplikes voorts 'n pasiëntspesifieke terapie ontwikkel, wat pasgemaak is vir die betrokke pasiënt se mediese toestand (Colman \& Kind 2000:192-196).

Die probleme met hierdie tegniek is dat ' $n$ lewensvatbare eiersel nie dadelik geskep word nie. Dit verg letterlik honderde pogings om te slaag. Terapeutiese kloning impliseer ook dat die embrio vernietig word nadat die stamselle onttrek is, en skep dus ' $n$ morele dilemma. Daar is boonop die vrees dat wetenskaplikes hierdie kennis kan misbruik om 'n menslike wese te skep. Met die nodige wetgewing en goeie beheer kan hierdie tegniek egter groot voordele vir siektegenesing inhou (Lanza, Cibelli \& West 1999:975-977).

\section{Navorsing oor en kliniese gebruike van stamselle}

Stamselle word tans gebruik om vrae in grondliggende en kliniese navorsing te beantwoord. Die volgende is die belangrikste navorsingsdeurbrake met stamselle:

\section{Funksionele genoomstudies}

In 1986 het Gossler en kollegas transgenetiese diere met behulp van muis-ES-selle geproduseer. Hiervoor is ' $n$ bepaalde geen by die muis-ES-selle gevoeg. 'Transgeneties' verwys na 'n stuk vreemde DNS wat by die organisme se genoom geïntegreer word. Dié DNS, of geen, kan deur die geenlyn na die nageslag oorgedra word. Hierdie tegnieke maak dit vandag moontlik om die funksie van soogdiergene en proteïene te bestudeer, deur histoversmeltbare gene in muise te plaas (Floss \& Wurst 2002:347-379; Stedman 2000:1134).

\section{Studie van biologiese prosesse}

Hierdie prosesse sluit die ontwikkeling van 'n organisme sowel as die kankerproses in, en geskied deur die naspeur en bepaling van stamselle se uiteinde. Till en McCulloch se navorsing oor die milt is ' $n$ voorbeeld van die ontwikkeling van bloedselle. In hulle navorsing het hulle enkele selle in swaar radioaktief bestraalde muise toegedien, sodat al die hematopoiëtiese selle in die muise hulle oorsprong by dié selle gehad het. Hierdie studies het gehelp om die kloningsoorsprong van kankerselle te ontleed (Till \& McCulloch 2006:2213-2222).

\section{Medisyneontwikkeling}

Die isolasie van muis-ES-selle saam met genetiese ingenieurstegnieke het tot die gebruik van ES-selle in medisyneontwikkeling gelei. Die bepaling van die menslike genoomvolgorde het 'n verskeidenheid nuwe potensiële teikengebiede vir medisyne ontsluit. Belangstelling in die gebruik van modelle vir stamselnavorsing op die gebied van toksikologie begin ook toeneem (Davila et al. 2004:214-223).

\section{Selterapie}

Gekweekte ES-selle vorm spontaan embroïede liggame wat seltipes van ál drie die primitiewe kiemlae bevat. Die gekose selle word geïsoleer en gekweek, waarna die gedifferensieerdes vir terapeutiese prosesse aangewend word. ES-selle is al gestimuleer om neurone, kardiomiosiete en endodermselle te vorm. 
Teen 1999 is selterapie al gebruik om meer as 50 verskillende siektes met verskillende grade van sukses te behandel. Hierdie siektes sluit leukemie (bloedkanker), borskanker, prikkelbare dermsindroom (IBS/irritable bowel syndrome) en osteogenesis imperfecta in (Kochar 2004:7). Osteogenesis imperfecta (sogenaamde 'brosbeensiekte') verwys na 'n oorerflike groep bindweefselafwykings van tipe I-kollageen (bindweefsel) wat tipies tot ' $n$ uiters breekbare beenstruktuur, frakture op minimale impak, beenvervorming, blou horingvliese van die oë, trae ligamente en gehoorverlies lei (Stedman 2000:1283).

\section{Terapeutiese potensiaal}

Die sleutel tot die terapeutiese potensiaal van stamselnavorsing lê in die begrip 'herskeppende geneeskunde' (regenerative medicine). Dit is ' $\mathrm{n}$ ontwikkelingsveld in die mediese wetenskap wat, soos uit die term blyk, gemoeid is met die ontwikkeling van mediese behandeling om beskadigde en verouderde weefsel te herstel, en die skade- en verouderingsproses om te keer (PetitZeman 2001:201-206).

Orgaan- en weefselskenkings word die afgelope paar jaar gereeld vir die behandeling van beskadigde en vernietigde weefsel gebruik, maar die vraag na hierdie skenkings oorskry verreweg die aanbod. Stamselle wat potensieel gestimuleer kan word om in verlangde weefseltipes te differensieer kan as ' $n$ hernubare bron van sel- en weefselvervanging dien om toestande soos Parkinsonisme, Alzheimersiekte, rugmurgbeserings, beroerte, brandwonde, hartsiektes, diabetes, osteoartritis en rumatoïede artritis te behandel (Donovan \& Gearhart 2001:92-97).

Hierdie deurbrake is hoofsaaklik die resultaat van die sogenaamde menslikegenoomprojek (MGP). Die MGP het reeds in 1988 in Amerika begin, en vinnig na ander lande versprei. Teen ' $n$ koste van etlike miljarde Amerikaanse dollar het die projek reeds meer as 17 jaar se navorsing onderneem.

\section{Voorlopige besinning}

Die in vitro-ontwikkeling van gespesialiseerde menslike selle het tot ' $n$ paradigmaskuif gelei. Wat aanvanklik net nóg ' $\mathrm{n}$ veronderstelling van wetenskaplike navorsing was, was skielik die potensiële ontwikkeling van selle wat selfs neurodegenerasieafwykings kan genees. Die etiese implikasies van hierdie navorsing is tans die onderwerp van hewige debatvoering en polemiek (Thomas, Dyck \& Kynaston 1999:120).

Dit is duidelik dat hierdie nuwe biotegnologiese verband waarin in vitro-bevrugting, die MGP, en stamselnavorsing en -terapie ' $n$ werklikheid geword het, nuwe uitdagings tot die samelewing en ook die teologie rig. Hierdie werklikheid vereis dat ons oor die etiese vrae van menslike lewe sal herbesin (Piazza 2002:9-21). In dié verband spreek Engels (2001:68) haar soos volg uit: 'Die rapiden Entwicklungen in Biologie und Medizin, insbesondere im Bereich der Biotechniken, stellen uns vor die Notwendigkeit einer grundsätzlichen Neubesinnung und Orientierung über unser menschliches Selbstverständnis als Natur- und Kulturwesen.' 1

\section{POLEMIEK}

\section{Maatskaplike polemiek}

Teenstanders van stamselnavorsing reken dat hierdie praktyke ons op die gevaarlike pad (slippery slope) na reproduktiewe kloning plaas, en dat dit die meganisering van 'n menslike wese behels (Kass \& Wilson 1998:42-46).

In teenstelling hiermee beweer sekere mediese navorsers uit 'n pro-keuse-hoek dat hierdie navorsing noodsaaklik is ter

1.'Die vinnige ontwikkeling in die biologiese en mediese wetenskappe, bepaald op die gebied van die biotegnologie, bring ons, as skeppings van natuur en kultuur, voor die noodsaaklikheid van behoorlike besinning en oriëntasie oor onsself (ons aard) te staan.' (vrye vertaling - S. Hoffman) wille van die terapeutiese voordeel wat dit kan meebring. Volgens hierdie suiwer terapeutiese benadering word daar in die maatskaplike debat aangevoer dat die voordele van stamselnavorsing die nadele wat embrioniese 'lewe' betref oorskry. Die groot verskeidenheid siektes wat potensieel met embrioniese stamselle behandel kan word, regverdig volgens hierdie benadering die vernietiging van menslike embrio's. Die koste van maatskaplike, ekonomiese en persoonlike verlies weens siekte weeg dus volgens hierdie siening swaarder as die verlies wat embriovernietiging meebring (Mason \& Dunnill 2008:351-363). Hierdie mediese navorsers beweer ook dat stamselnavorsing net daardie embrio's gebruik wat in elk geval bedoel is om as ' $n$ produk van in vitro-bevrugting vernietig te word. Teenoor hierdie navorsers staan die 'pro-lewe'-beweging, wat argumenteer dat ' $n$ embrio ' $n$ menslike wese is, en daarom geregtig is op waardigheid en selfs wetlike beskerming (Dombrink \& Hillyard 2007:189-195).

Die pro-lewe-argument berus op die aanname dat embrioniese lewe as gelykstaande aan volwasse menslike lewe beskou word. Sodra ' $n$ eiersel bevrug is, verteenwoordig dit die begin van menslike lewe. Voorts beskou pro-lewe-aanhangers menslike lewe op sigself as waardevol; iets wat nie vernietig mag word nie - selfs nie om ander te red nie. Hulle voer hierdie argument verder deur te sê dat navorsers wat die etiese implikasies van die vernietiging van menslike embrio's ontken of afmaak, menslike lewe geringskat. Hierdie beweging hou die politieke en etiese standpunt voor dat alle menslike wesens die reg het op lewe, en dat dié reg ook fetusse en embrio's geld. Die bestek van menslike lewe begin dus volgens hulle by bevrugting, en eindig in biologiese dood (Monroe, Miller \& Tobis 2008:138-141).

Hierdie debat noop wetgewers wêreldwyd om na etiese verwysingsraamwerke te soek ten einde maatskaplike en wetlike riglyne neer te lê. Die hewige maatskaplike reaksie en polemiek oor stamselnavorsing en -terapie is genoeg bewys van die sensitiwiteit van die saak. Natuurwetenskaplikes en denkers behoort die publiek se gevoelens oor die etiese aspekte van hul navorsing of opinies te respekteer. Hoewel hierdie gevoelens nie as norm vir besluitneming uit ' $n$ Christelik-etiese hoek dien nie, vereis ' $n$ ekoteologiese ingesteldheid steeds dat die eksistensiële vrae en worsteling in die maatskaplike sfeer in ag geneem word.

\section{Politieke reaksies}

Weens 'n gebrek aan ruimte is slegs ' $n$ oorsigtelike bespreking van internasionale wetgewing moontlik. Eers word die SuidAfrikaanse bydraes en wetgewing egter in meer besonderhede bekyk.

Suid-Afrika was die eerste Afrikaland wat 'n stamselbank ontwikkel het. Hoewel Suid-Afrikaanse wetgewing die beperking op reproduktiewe kloning behou, keur die owerheid die terapeutiese kloning van embrio's goed. Die Suid-Afrikaner Mark Shutteleworth het ook in 2002 stamsel-eksperimente in die swaartekragvrye omgewing van die buitenste ruimte uitgevoer. Suid-Afrika se wetgewing maak hoofsaaklik vir die beheer van stamselhantering voorsiening. Die Nasionale Gesondheidswet, Wet 61 van 2003, bevat wél regulasies ten opsigte van die gebruik, hantering en optekening van stamselle, maar bevat geen riglyne oor die basiese etiese beskouing van embrio's en stamselle nie. Stamselgebruik en -hantering word tot die volgende beperk:

- Gebruike wat ingevolge artikel 54 van die Gesondheidswet goedgekeur word.

- Laboratoriumtoetse ten opsigte van die jongste inligting oor aansteeklike genetiese siektes.

Terapeutiese gebruik is voorts onderworpe aan die volgende:

- registrasie by die Departement van Gesondheid ingevolge regulasie 3(3)(a)

- toepassing van die regulasies oor stamselgebruik en -hantering 
- die skenker se skriftelike toestemming (geld ook residuele weefselselle)

- verkryging van vrywillige skenkings

- $\quad$ slegs terapeutiese en opvoedkundige gebruike.

(Nasionale Gesondheidswet, Wet 61 van 2003 paragraaf 1.2 .1$)^{2}$

Wat internasionale wetgewing betref, is daar nie juis duidelike riglyne oor menslike embrioniese navorsing nie. Koller (2002:19) maan dat die huidige wetgewing in die meeste lande nie voldoende is om ongerymdhede wat uit stamselnavorsing en -terapie kan spruit, te vermy nie.

Die etiese verantwoordelikheid vir voldoende kommunikasie tussen wetenskaplikes en die algemene publiek, wat politieke en kulturele instellings insluit, rus op regerings. Bepaalde temas kom wel ter sprake, maar die algemene opvatting dat wetenskap net aan 'n uitgesoekte groep behoort, heers steeds. Kennis van die komplekse etiese uitdagings sal die publiek die vrymoedigheid gee om sinvol tot die debat by te dra (Piazza 2002:29-31)

Daar is ' $\mathrm{n}$ direkte band tussen die grondbeginsel van menslike waarde, en tegnologiese ontwikkeling. Die oorspronklike antroposentriese begrip van menswaardigheid sluit nie alternatiewe vertolkings uit nie. Die antroposentriese begrip van waarde kan plek maak vir 'n regstelling en aanpassing van hoe die mens beskou word. Die vertolking van die Grondwet moet aan die hand van menslike ontwikkeling aangepas word. Menswaardigheid is ' $\mathrm{n}$ goeie voorbeeld van die hervertolking van die status quo, aangesien dit nie ' $\mathrm{n}$ statiese begrip behels nie, maar eerder ' $n$ dinamiese, ontwikkelende beskouing van die menslike wese veronderstel. Die algemene aard van oorkoepelende waardes soos menslike waarde lei daartoe dat die Grondwet ook op maatskaplike en kulturele ontwikkeling van toepassing is (Simon 2002:40-44).

Die gedagte van menslike waarde is volgens Shapira (2002:75-77) gewoonlik baie vaag en ontwykend. Hy wys daarop dat hierdie konsep hoogs kultureel afhanklik en waardegevoelig is. ' $n$ Samevoeging van die algemene transkulturele en transnasionale omskrywings van die konsep blyk gans onmoontlik te wees. Eenvormige en algemeen aanvaarbare antwoorde op hierdie dilemma is volgens hom nie maklik te vind nie. Die komplekse en diverse kontoere van die konsep 'menswaardigheid' verg dus verdere ondersoek. Verfynde epistemologie moet volgens Tallacchini (2002:88-89) 'n wisselwerking tussen feite en waardes handhaaf waarin elke standpunt erken word. Openbare keuses is die komplekse produk van wisselwerking tussen teoretiese ontledings of feitelike oorwegings, en die breër aksiologiese verband waarin dit funksioneer.

Finnis (2002:104-106) waarsku teen die aanname dat enige persoon op grond van blote feite, etiese of normatiewe afleidings oor mense se opinies kan maak. Volgens hom oortref Duitse wetgewing in dié verband die Britse standpunt wat moraliteit en rasionaliteit betref. Die druk van die openbare opinie toon ook 'n interessante dinamiek. Etiese owerhede in die mediese beroep het byvoorbeeld jare lank Robert Edwards se navorsing oor in vitro-bevrugting (IVF) veroordeel, maar sy tegnologiese sukses het daartoe gelei dat dieselfde kritici hom later aangemoedig en lof toegeswaai het. Openbare druk lei immers nie noodwendig altyd tot etiese besluitneming nie.

Hedendaagse regstelsels staan tans voor die uitdaging om wetenskaplike praktyk en die produk daarvan op 'n gepaste wyse te reguleer. ' $\mathrm{n}$ Middeweg is nodig tussen die eng besluite om menslike kloning hetsy heelhartig goed te keur of geheel en al af te keur. Gedagtig daaraan dat individuele nasionale wetgewers nog nie 'n enkele koersvaste wetlike beleid oor die kwessie kon neerlê nie, is daar nog baie te doen om 'n breër en meer geartikuleerde verhouding tussen die wetenskap en die wet in die hand te werk (Mazzoni 2002:5-7).

2.Kyk ook http://stemcells.nih.gov/index.asp, http://pewforum.org/docs/?DoclD=318, http://www.npr.org/templates/story/story.php?storyld=5252449, en http://www.ncs
org//ssuesResearch/Health/EmbryonicandFetalResearchLaws.
Uit bogenoemde debat in die politieke sfeer blyk duidelik dat daar nog geen algemene konsensus oor wetgewing is nie. Christelik-etiese beskouinge kan uit 'n ekoteologiese hoek sinvol tot die politieke debat en etiese vrae oor besluitnemingsriglyne bydra.

\section{CHRISTELIKE ETIEK}

Die woord 'etiek' kom van die Griekse woord ethikos, wat onder andere met 'lewenswyse' vertaal kan word. Vir die onderhawige doeleindes sal etiek beskou word as die onderdeel van filosofie wat die grondbeginsels en -konsepte van morele optrede bestudeer (Wyschogrod \& McKenny 2003:1-5). Etiek kan ook as die wetenskap van sedelike norme of wette omskryf word, wat ook as sedeleer of sedekunde (Odendal \& Gouws 2005:224) of 'rules of human behaviour, norms of Christian conduct' (Deist 1992:87) bekend staan.

Hierdie omskrywings verskraal egter waarskynlik die dinamiese aard van etiek. Indien dit so eng omskryf word, handel dit slegs oor die ondersoek van konsepte van wat reg en verkeerd, en goed en kwaad is, en wat 'verantwoordelikheid' beteken. Etiek is egter veel dinamieser, en verreken die komplekse aard van ons relasionele bestaan (Böhme 2001:2).

Histories beskou, is etiek sedert Plato se tyd deurgaans nou verwant aan maatskaplike gemeenskappe en politiek. Politieke besluitneming verg immers etiese besinning. Die feit dat 'n individu nooit heeltemal geïsoleerd van die samelewing kan bestaan nie, veronderstel dat daar geen absolute onderskeid tussen etiek en politiek gemaak kan word nie (Plato Rep VI). Selfs die onderskeid tussen sogenaamde persoonlike en maatskaplike etiek blyk geforseerd te wees (Clark 1973:220).

Die feit dat die Griekse woord ethos in die betekenisveld van die begrip 'karakter' of 'aard' staan, is egter eweneens veelseggend. Die term verwys in die algemeen na die waardes in ' $n$ bepaalde gemeenskap of maatskaplike groep. Ons kan byvoorbeeld sê die Puriteinse etos behels die beklemtoning van harde werk as ' $n$ maatskaplike waarde (Weber, Baehr \& Wells 2002:9-16).

Etiek handel nie net oor kliniese wette of reëls nie, maar hou verband met ' $\mathrm{n}$ breër begrip van die menslike aard (Dreyer 1979:1), en die relasionele aard van antropologiese bestaan. Die rol wat die Bybel ten opsigte van etiese besluitneming speel, word noodwendig ook deur ' $n$ breër begrip van etiek beïnvloed. Die verbreding van die begrip 'etiek' en 'Christelike etiek' vereis ook ' $n$ herbesinning oor die Skrif. Die proses van etiese besinning behoort ag te slaan op stemme en perspektiewe uit verskeie etiese hoeke. Gebalanseerde etiese besinning is slegs moontlik wanneer daar in die dinamiese gebeure van die debat ontvanklikheid en respek vir verskillende standpunte bestaan.

Etiek kan ook nooit onafhanklik van teologie bedryf word, of suiwer op menslike of selfs praktiese rede gegrond word nie. Etiek vereis altyd 'n saamgestelde tradisie, naamlik dié van narratief en stories in ' $\mathrm{n}$ geestelike gemeenskap, wat só aan die mens betekenis gee (Buitendag 2005:15).

Wêreldbeskouings en die werklikheidsbegrip het mekaar in dié dialoog wedersyds beïnvloed. Hierdie kruisbestuiwing van gedagtes en idees maak dit soms moeilik om die Westerse etiek van etiese perspektiewe uit die Christendom te onderskei. Aan die een kant vererger hierdie verband die probleem in $\mathrm{B}$ multikulturele omgewing soos Suid-Afrika (Pack-Brown \& Braun Williams 2003:57-59). Aan die ander kant beskou baie weer die spanning tussen perspektiewe uit bogenoemde twee hoeke as 'n dinamies-kreatiewe probleem (McGrath 1995:28-54).

Die postfondamentalistiese argument in verband met evolusionêre epistemologie lei ons verby die punt van 'n gedwonge keuse tussen naturalisme of radikale supernaturalisme. 
Hedendaagse wetenskap bied 'n geleentheid vir interdissiplinêre gesprek tussen teologie en wetenskap, waar gedeelde belange en moontlike epistemologiese oorvleueling moontlik is. Hierdie voortdurende gesprek kan tot ' $n$ grasieuse duet tussen hierdie twee benaderings tot die realiteit lei (Van Huyssteen 1998). Volgens dié siening kan godsdienstige en teologiese besinning in 'n transversale ruimte die interdissiplinêre gesprek as gelyke vennote betree, waar die stem van godsdienstige lojaliteit in die postmoderne, pluralistiese situasie gehoor kan word. Teologiese besinning beskik dus oor dieselfde standaard van rasionaliteit as ander dissiplines: Hoewel dit altyd maatskaplik en kontekstueel gevorm word, is dit nie onherroeplik kultuur- en konteksgebonde nie. Selfs met wyd uiteenlopende persoonlike godsdienstige of dissiplinêre perspektiewe, bly geld die ryke bron van menslike rasionaliteit (Van Huyssteen 1998:159-166).

Ricoeur (1992:210-240) wys daarop dat morele oorweging intrinsiek verbind is aan die vertolking van die morele self in wisselwerking met ' $n$ gemeenskap. Verskillende filosofiese agtergronde, perspektiewe en tradisies (oftewel raamwerke) se bydrae tot ' $n$ begrip van die etiese aspekte van stamselnavorsing en -terapie moet dus nooit geringgeskat word nie. Die Christelik-etiese besinning oor hierdie saak kan net baat vind by ' $\mathrm{n}$ bereidheid om na soveel moontlik stemme uit verskillende hoeke te luister.

Christelike etiek kan verstaan word as ' $\mathrm{n}$ dinamiese netwerk bedryfswaardes en -deugde wat uit verskillende hoeke en tradisies ingevolge narratiewe beskrywing en vertolking die waarde en sin van relasionele bestaan weerspieël. Hierdie waardes, deugde en karaktereienskappe draai om die konsep van liefde soos dit in die Skrif omskryf word (Browning 2006:5556). In die praktyk is die etos van die Christelike gemeenskap ' $n$ stroom wat konstant tussendeur die Christelike etiek, en die etos van die algemene kultuur en groter gemeenskap waarin die kerk bestaan, vloei.

Die logiese afleiding is dat Christelike etiek en die Christelike etos in die hedendaagse tyd en wêreld eerder ' $n$ dinamiese strewe as ' $n$ statiese toestand veronderstel. Die vraag na Christelik-etiese riglyne sal dus tersaaklik bly solank daar ' $n$ Christelike gemeenskap is wat na antwoorde en betekenis op soek is. Die etos van die Christelike kerk kan om dieselfde rede nooit in ' $n$ stagnante gietvorm van fundamentalistiese versekerdheid verval nie, maar behoort in die gesprek met die wêreld organies te groei en aan te pas. Christelike oortuigings maak ' $\mathrm{n}$ narratief uit wat noodwendig ' $\mathrm{n}$ transformasie van die mens se selfbegrip vereis. Christelike etiek handel dus oor die dinamiese proses waardeur die mens telkens genooi word om te groei tot ' $n$ deel van die verhaal van God en die mens. Die verbreding van die narratief van selfbegrip lei spontaan tot versmelting met die narratief van Jesus as die koninkryk van God (Hauerwas 1991:28-36).

\section{BRANDPUNTE IN DIE HUIDIGE TEOLOGIESE DEBAT}

Peters (2007:28) wys die volgende drie basiese raamwerke of brandpunte in die huidige teologiese debat uit:

1. Die beskerming van die embrio.

2. Die beskerming van die natuur.

3. Die mediese voordele.

In elke raamwerk bestaan daar argumente vir of teen stamselnavorsing, alhoewel die eerste twee deur teenkanting, en dielaaste een deur ondersteuning oorheers word. Peters noem ook 'n vierde raamwerk, naamlik 'n 'navorsingstandaarderaamwerk'. Die eerste indruk is dat hierdie raamwerk bloot sekulêr is, omdat dit deur openbare beleidmakers en laboratoriumnavorsers oor die wêreld heen gebruik word. Die raamwerk spel die etiese en soms wettige praktyke en prosedures uit aan die hand waarvan regeringsfinansiering onder andere toegestaan word (Peters
2007:28). By nadere ondersoek blyk hierdie riglyne egter ' $n$ samevoeging van prinsipes sonder enige duidelike samehang te wees. Peters skryf hierdie verskynsel aan die gaping tussen ' $n$ teologies gegronde raamwerk en die sekulêre raamwerk toe. Wetenskaplikes werk in 'n sekulêre etiese raamwerk, wat op sy beurt die morele standaarde bepaal aan die hand waarvan hulle hulself beoordeel. Die morele grondslag van hierdie standaarde verdwyn egter. Die probleem met hierdie situasie, waar etiese reëls of standaarde apart van 'n teologiese en filosofiese grondslag funksioneer, is vanselfsprekend. Peters (2007:76-88) dui daarop dat elkeen van hierdie standaarde tóg in een van bogenoemde vier raamwerke tuishoort om daar teologies verantwoord te word.

Die huidige teologiese debat behels twee uiteenlopende standpunte - streng konserwatisme wat stamselnavorsing en -terapie voor die voet as sonde veroordeel, en die beskerming van die embrio as absoluut voorhou (Solo \& Pressberg 2007:9596), teenoor totaal liberale en pragmatiese argumente wat stamselnavorsing en terapie onvoorwaardelik as wonderkuur aanvaar, en die mediese voordele verabsoluteer (Siegel et al. 2006:1-2). Tussen hierdie uiterstes is daar ook stemme wat versigtiger oor die kompleksiteit van die verskynsel dink en praat (Peters 2007:100-110; Sandal 2007:112-113).

Daar is egter ook ' $n$ derde standpunt oor stamselnavorsing. Dié benadering erken en waardeer die navorsing se wonderlike potensiaal om pyn te verlig en siektes te genees, maar begryp terselfdertyd die verantwoordelikhede en etiese implikasies wat dit meebring. Dit getuig van ' $n$ opregte waardering vir voorregte, $d$ og ' $n$ diepe bewustheid van die verantwoording wat dit vereis.

Ekoteologies word menslike waarde deur ander, die natuur en God bevestig. Die waardering vir ander berus immers op die geloofservaring dat God aan ons waarde heg. Handelinge van dankbare liefde spruit uit die erkenning van intrinsieke waarde. In hierdie sin word persone as ' $n$ doel op sigself, en nie slegs as middele tot ' $n$ doel hanteer nie. Peters (2007:100) staaf bogenoemde standpunt deur na 1 Johannes 4:11-12 te verwys:

Geliefdes, as dit is hoe God sy liefde aan ons bewys het, behoort ons mekaar ook lief te hê. Niemand het God nog ooit gesien nie, maar as ons mekaar liefhet, bly God in ons en het sy liefde in ons sy doel volkome bereik.

Peters (2007:100-101) wys op twee uitsonderlike kenmerke wat uit ' $n$ relasionele begrip van antropologiese bestaan spruit: Die eerste is die universele perspektief van heling of welstand (wellbeing), en die tweede die toekomsgerigte perspektief wat ook transformasie by genesing en geestelike heling insluit.

God se liefde vir ons hang nie van ons genetiese samestelling af nie. Die getuieniskrag van Jesus se optrede gedurende sy aardse bediening leer ons ook om nie die waarde van mense aan natuurwetenskaplike of rasioneel bewysbare maatstawwe te onderwerp nie. Jesus reik uit na die nederigste en 'minswaardige' persone binne én buite die gemeenskap. Erkenning van menswaardigheid in die relasionele verband van ons bestaan impliseer dus nie dat waarde ontologies in die biologie of genoom van die mens opgesluit is nie. ' $n$ Soeke na die aard van menslike waarde as intrinsieke eienskap in die gene sal vrugteloos wees. Uit ' $n$ ekoteologiese hoek is die erkenning van menslike waarde ' $n$ dinamiese gebeurtenis wat deur die verhouding met God in sy skepping plaasvind en daaruit spruit. Waarde lê dus opgesluit in die energie van hierdie verhouding, en nie in die materie van die DNS nie.

Dié debat laat ons besef dat die wonder van menslike lewe nie deur ' $n$ monolitiese waarheidsbegrip of atomistiese sieninge vasgevang en verklaar kan word nie, maar noop ons om ons verstaanshorisonne te verbreed, wat in ' $\mathrm{n}$ relasionele begrip van menswees ook die bosintuiglike (transendente) en selfs die onverklaarbare insluit. In die soeke na 'n derde benadering tot 
die kwessie van stamselnavorsing en -terapie het dit duidelik geblyk dat 'n breër begrip van die relasioneel-antropologiese menslike bestaan tot nuwe perspektiewe kan lei. Hierdie derde benadering is dan ook die raamwerk waarin ons verder oor hierdie komplekse vraagstuk sal besin.

\section{EKOTEOLOGIESE BESKOUING VAN ETIEK}

\section{Wat is ekoteologie?}

Die Duitse bioloog Ernst Haeckel het die term 'ekologie' die eerste keer in 1866 omskryf, en wel as die 'comprehensive science of the relationship of the organism to the environment' (North 1995:189).

Die woord 'ekologie' is 'n samestelling uit die Griekse begrippe oikos (huis of woonplek) en logia (woord of studie). Die woord hou derhalwe verskillende betekenismoontlikhede in, soos 'studie oor [ons] huis' of 'woorde oor [ons] huis'. Ekologie kan ook as die wetenskaplike studie van die verspreiding en oorvloed van lewe, en die wisselwerking tussen organismes en hul natuurlike omgewing (biotoop) beskryf word. Die omgewing van ' $\mathrm{n}$ organisme sluit fisiese én chemiese faktore in. Hierdie omgewing kan as die som van plaaslike faktore, geologie, biologiese ekosisteem, en ander organismes wat in dieselfde habitat bly, beskou word (Begon, Townsend \& Harper 2006:1-8).

Met betrekking tot $\theta \varepsilon o \lambda o \gamma$ ía ('woorde oor of van God' of 'die studie oor God') (teologie), is ekoteologie dus 'n beskouing van die verhouding tussen Skepper en skepping. Nürnberger beskryf teologie as die akademiese poging om die boodskap van God se reddingsdaad in Christus te bestudeer in soverre dit ons raak en betrek (Nürnberger 1975:67). Edwards voeg hierby dat ekoteologie op die openbaring van God in die ruimte van die geskape werklikheid konsentreer (Edwards 2001:46-48; 195-198).

Die gedagte dat die mens as verteenwoordiger die taak het om God se heerskappy op die aarde 'af te dwing' stem 'n mens egter ongemaklik. Le Roux (1991:49-49) wys dan ook tereg daarop dat bogenoemde siening gekwalifiseerd oorweeg moet word, met waardering vir die klem op die 'besigwees' met die aarde. Le Roux beklemtoon derhalwe die belang van 'n heroorweging en nuwe formulering van die mens se plek in die skepping. Hy voer aan dat die 'beeldwees' van die mens onder andere as 'n verhoudingswoord/-saak begryp moet word. Die ekologiebewuste en -sensitiewe aard van die hedendaagse tyd vereis ' $n$ beskouing van die mens as beeld van God van in ekoteologiese uitgangspunt. Hy verwoord die doel van ekoteologie soos volg: 'Ons eko-teo-logie kan dus nie afstuur op 'n ekologie an sich nie, maar op 'n eko-teo-logie wat die relasie God-mens-wêreld in dinamiese perspektief wil raaksien' (Le Roux 1991:49).

Antroposentriese etiek kan nie meer deug nie. 'n Verskraalde beskouing van die omvang van die werklikheid lei tot etiese dwaling. Verantwoordelike etiek is slegs moontlik wanneer die werklikheid so breed moontlik beskou word (Le Roux 1991:497-510). Deane-Drummond (2006:79-80) beklemtoon die waarde van die besef dat teologiese tradisies nie in ' $n$ kulturele vakuum funksioneer nie. Hierdie interdissiplinêre aard van 'n ekoteologiese benadering maak dit moontlik om belangrike aspekte van die verhouding tussen God, die mensdom en die natuur, met sekulêre en selfs ander godsdienstige tradisies in gesprek te stel. Sy beklemtoon egter ook dat die mees insiggewende bron vir die ekoteologie steeds die Bybelse teks is. Uit hierdie tradisie word daar teologies besin.

Ekoteologie blyk dus die krities waarderende besinning oor die multidimensionele verhouding tussen God en die mens, binne die kader van die skepping, en aan die hand van die gesprek tussen teologiese en ander perspektiewe te wees. Eko-etiek is nie ' $n$ monolitiese oefening wat deur eensydige uitgangspunte en finale gevolgtrekkings begrens word nie. Kasuïstiese, finale antwoorde wat deontologies gegrond of bewys word, hoort dus nie in 'n ekoteologiese begrip nie. 'n Ekoteologiese benadering veronderstel ontvanklikheid vir verskillende sieninge en uitgangspunte in die besinning oor morele vraagstukke. Die kuns van ' $n$ gebalanseerde ekoteologiese etiek is om aan die een kant nie in deontologiese eensydigheid, en aan die ander kant nie in ' $n$ teleologiese pragmatisme vas te val nie (Buitendag 2004:412).

Hierdie verbreding van die begrip van die mens in bepaalde verhoudinge lê ten grondslag aan die ekoteologiese vraagstuk na stamselnavorsing en -terapie.

Die vereiste antropologiese herbesinning sal uit 'n ekoteologiese hoek ook die kosmologiese aspekte van relasionele bestaan moet verreken. In 'n eko-etiese besinning behoort die natuurlike en kosmiese aard van die menslike bestaan wat ruimte en tyd betref, ' $n$ inklusiewe waardering vir die kompleksiteit van menslike denke, emosies en gedrag teweeg te bring.

Buitendag (2004:415) beklemtoon ook die belang van die kruisgebeure in die eko-etiek. Hy bring dit in verband met die noodkrete van die mens, soos dit in Eksodus 3:7 verskyn, die verlossingsug van die natuur in Romeine 8:22, en die weerklinkende kreet van Jesus aan die kruis van Golgota in Markus 15:37.

In hierdie dialektiese spanning van lyding en dood teenoor opstanding en lewe word die verhouding tussen God, die kosmos en die mens sigbaar. Die relasionele werklikheid word dalk die beste in Markus 15:38 verwoord wanneer die voorhangsel skeur sodra Jesus sy laaste asem uitblaas.

Buitendag dui op die eskatologiese waarde van so 'n relasionele werklikheid, so 'n planetêre solidariteit, in die sin dat die hede hier prolepties die toekoms ontmoet. Geloof lei dus tot hoop, en hoop tot handeling (Buitendag 2004:415).

Susan Power Bratton (1998:111-115) som die plek en begrip van ekoteologie en eko-etiek goed op. Sy wys daarop dat ekoteologie, anders as abstrakte kosmologie of teologie van die natuur, die Christen tot wisselwerking met die natuur wil lei.

Ekoteologie handel oor die waarde van ander skepsels, en God se bedoeling met die kosmos. Dit ontwikkel ook etiese modelle wat die politiek, ekonomie en praktiese aspekte van die verhouding tussen die mens, die natuur en God verreken. Sy stel dit ook duidelik:

Although Christian ecotheology cannot replace intelligent environmental policy, it can encourage constructive engagement with environmental problems and inspire us to better environmental care.

(Bratton 1998:111)

Op grond van so 'n begrip van eko-etiek, kan daar krities oor die Christelik-etiese implikasies van stamselnavorsing en -terapie as 'n faktor in die verhouding tussen God, die mens en die natuur besin word.

\section{EKOTEOLOGIESE ANTROPOLOGIE}

\section{Antropologie}

Christelik-etiese beskouinge van die aard en wese van die mens word deur bepaalde perspektiewe in die studie van antropologie beïnvloed. Daarom is ' $\mathrm{n}$ gesprek met die natuurwetenskappe en antropologie nodig (Ott 1981:170-181). Alhoewel daar van ander begrippe en omskrywings gebruik gemaak word om die mens op grond van die natuurwetenskappe of antropologie te beskryf, is dit nodig dat teoloë na die vertolkings wat ander wetenskappe bied, sal luister. Die dialoog tussen teologiese antropologie en geesteswetenskaplike antropologie is op sigself insiggewend (Davies 2002:1-19). Ook Heyns en Jonker gaan hiermee akkoord: 'Mens-wees beteken o.a in-die-wêreld-wees, en dit impliseer besig-wees-met-die-wêreld. Wie in die wêreld 
is en met die wêreld besig is, weet van die wêreld en kry kennis van die wêreld' (Heyns \& Jonker 1977:20)

In sy lesings oor 19de-eeuse teologie by die byeenkoms van die Goethegesellschaft in 1957, bied Karl Barth ' $n$ interessante beskouing van die teologie, wat tradisioneel as 'die wetenskap en doktrine oor God' beskou is, wanneer hy dit as 'Die Antropologie' beskryf. Hiermee probeer Barth toon dat daar nie in die Christelike ruimte van 'n suiwer doktrine oor God gepraat kan word nie. Dit gaan altyd oor 'God en die mens', met ander woorde ' $n$ doktrine van handeling, gemeenskap en verhoudinge. In dieselfde sin verwys die woord 'evangelie' na die kennis van die blye boodskap oor Jesus Christus. 'Evangeliese teologie' handel dan volgens Barth oor die 'wetenskap en doktrine van die handeling en gemeenskap tussen God en die mens, soos dit uit die evangelie van Jesus Christus blyk wat in die Heilige Skrif verkondig word' (Barth 1960:11).

In die huidige antropologie het 'n verskuiwing ten opsigte van die tradisionele, streng positivistiese begrip plaasgevind. Eric Wolf (1923-1999) verwoord hierdie hermeneutiese uitgangspunt deur antropologie as die mees wetenskaplike van al die menswetenskappe, en die 'menslikste' van al die wetenskappe te beskryf (Wolf 1964:88).

James Lett (1996) beskryf later hierdie nuwe dinamiese verhouding soos volg:

Since its inception the discipline of cultural anthropology has had a dual identity, embracing simultaneously both the humanistic and scientific perspectives. While there have always been strong partisans for one side or the other. . . most anthropologists have taken a more eclectic approach and combined the two . .

(Lett 1996:1141)

Die dinamiese aard van die gesprek tussen antropologie en teologie ontsluit as wisselwerking ook nuwe begripsmoontlikhede op albei gebiede. In die lig hiervan stel Peters dit dat die stamseldebat uit die sekulêre wêreld 'n samehangende en inspirerende dogma oor die menslike karakter en aard vereis, wat as grondslag vir openbare beleid kan dien (Peters 2007:89).

Volgens Buitendag (1999) is dit ' $n$ 'vrugtelose soektog' om in die Bybel ' $n$ fyn uitgewerkte leer oor die mens te probeer vind. Die Bybel bevat nie ' $n$ leer oor die mens op sigself nie, maar praat oor die mens aan die hand van die relasionele aard van ons bestaan. Daarom merk Buitendag tereg op: 'Wie die raakvlak tussen God en mens binne die geopenbaarde grense van die Skrif geformuleer kry, het by 'n Bybelse antropologie uitgekom' (Buitendag 1999:322).

Relasionele begrip van antropologiese bestaan as moontlike reaksie op die vraag oor die waarde van menslike lewe: Anders as in positivistiese natuurwetenskap, word die mens in Bybelse antropologie nie as statiese onderwerp van studie en ontleding beskou nie, maar eerder as dinamiese wese wat in 'n holistiese netwerk van intersubjektiewe verhoudinge bestaan. Bybelse antropologie ontmoet die mens as lewende wese wat coram deo ('voor die aangesig van God') bestaan. Die Godsbeeld wat in so 'n Bybelse antropologie ontwikkel, is dus ook nie staties nie, maar ontwikkel uit ons verhoudinge met God deur Jesus Christus, en met mekaar as broers en susters. Bybelse antropologie is dus nie ' $n$ vae leer oor 'die mens' as abstrakte begrip, of ' $n$ reduksionistiese ontleding van die mens as onafhanklike individu nie, maar eerder ' $n$ begrip van die mens as konkrete wese in die eksistensiële dimensies van ruimte en tyd. Antropologie en soteriologie is volgens Luther keerkante van dieselfde munt (Buitendag 1999:323).

Geskapenheid moet ook nie as statiese en afgehandelde begrip verstaan word nie. Christene bely immers dat God die Skepper ís, en nie dat Hy die Skepper wás nie. Ons ontmoet ook die werklikheid van 'die skepping' opnuut in elke oomblik van ons bestaan. Skepping en geskapenheid verloor alle tersaaklikheid sonder die konstante vloei van die herskape werklikheid waarin ons bestaan. Die relasionele begrip van die mens bied ' $n$ goeie riglyn vir antropologiese vertolking. Anders as die tradisionele pogings om die menslike aard en karakter op die skeppingsorde te grond sal ' $n$ eskatologiese beskouing van die mens in die huidige debat dalk van meer waarde wees. Die vraag 'Wat is die mens?' lei slegs tot frustrasie indien ons die ontologiese waarde van die mens met kunsgrepe uit die natuurwetenskap en onseker filosofiese argumente probeer vaspen. Miskien moet ons eerder vra 'Wie is die mens?', en dit dan in die Christelike etiek op grond van ' $\mathrm{n}$ beskouing van die 'nuwe skepping' probeer beantwoord (Peters 2007:89).

Op grond van 'n eskatologiese siening van die mens as relasionele wese, word rigiede antropologiese verklarings in ' $n$ dinamiese besinning, wat ' $n$ antisiperende (of proleptiese) antropologie genoem kan word, omvorm. Die vraag is of so ' $n$ antropologiese perspektief etiese oriëntasie kan verander. Sal ' $n$ antisiperende antropologie alternatiewe beskouinge van die vraag oor die waarde van menslike lewe kan bied?

Die belofte van die opstanding en die nuwe skepping lê nie op streng individualistiese vlak nie. Die belofte van heling setel in die advent van die heling met betrekking tot die ganse gemeenskap, en dan ook ekologies beskou, met betrekking tot die ganse kosmos. Pannenberg (2004:5222-5227) verwoord sy siening van die menslike bestaan as antisiperende of proleptiese gebeure. Identiteit in die huidige bestaansdimensies veronderstel die toekoms van die mensdom en die kosmos, wat volgens Pannenberg onlosmaaklik aan mekaar verbind is.

Die menslike identiteit het sy grondslag in die verhouding van die Drie-eenheid. Die heilige interne verhouding in die Drieeenheid maak die kader uit van die mens se relasionele bestaan. Gemeenskap met God die Vader in Christus en die Heilige Gees gee sin en betekenis aan die menslike bestaan in die verhouding met God as persoonlike wese, én met ander (LaCugna 1991:15).

Die dinamiek van die interrelasionele bestaan van die mens kan ook op grond van Whitehead se prosesteologie as die eenheid van alle dinge met God in ' $n$ interaktiewe vloei van tyd en ewigheid beskou word (Pannenberg 1996:367).

Bybelse antropologie behels die raakvlak tussen God en mens binne die geopenbaarde grense van die Skrif. Die kennis van die mens wat ons in die Bybel kry, is alleen maar dié van die sondaarmens voor God, en altyd in hierdie wêreld:

' $n$ Wêreld wat God geskep het deur die Gekruisigde, wat vir die sonde van die wêreld gesterf het, en dit ook oorwin het. En in die verwagting van die finale herstel leef die mens nog altyd.

(Buitendag 1999:322)

Miskien kan iets van hierdie wisselwerking in die soeke na menslike identiteit ook in die ontmoetingsgebeure tussen Moses en God in Moses se natuurlike omgewing raakgesien word (Eks 3:11-14). Die 'wie is ek?'-vraag kan slegs verklaar word in verhouding tot die 'wie Ek is'-antwoord.

Die gedagte van ' $n$ holistiese interafhanklikheid, wat selfs die grense van rasionele bewustheid en kennis oorskry, is ' $n$ teken van ' $n$ breër antropologiese begrip van die kompleksiteit en misterie van die menslike relasionele bestaan.

Buitendag (1999:337) wys daarop dat die beeld van God sowel die indikatief as die imperatief behels. Die mens vind sy/haar waardigheid voor God juis in die nederige eerbied wat na vore kom wanneer die goddelike en die menslike ontmoet.

In die kleinword voor God, en die verklaring van God se grootheid, word die vraag 'Wie is die mens?' dan die vraag 'Wie is U, Here?' (Hand 9:5).

\section{BASIESE RIGLYNE VIR CHRISTELIK-ETIESE BESLUITNEMING}

Verbreding van die oikos-begrip

Die oikos- (huis-)begrip het verskeie betekenismoontlikhede (Pomeroy 1999:67). Die verwysing na huis of woning kan letterlik 
verstaan, maar ook simbolies vertolk word. Die verbreding van hierdie begrip ontsluit bepaalde beskouinge van die verhouding tussen God en die mens in die ruimtelike aard van ons bestaan Oikos dui in hierdie sin op die breë relasionele verband waarin die mens se verhouding met ander, die omgewing, die toekoms en die bosintuiglike, onder andere, dog nie uitsluitlik nie, die vraag oor die mens se identiteit kan beantwoord. Vrae soos 'Wie is ek?' of 'Wat is die mens?' kan in die breër begrip van die oikos net met betrekking tot die multidimensionele netwerk van verhoudinge waarin die mens bestaan, beantwoord word.

'n Ekoteologiese perspektief lei ons deur middel van 'n relasioneelantropologiese begrip van menswees tot ' $n$ voortdurende bewustheid van ons verhouding met die Huiseienaar. In hierdie verwagting van die koms van die Heer van die huis vind ons die eskatologiese hoop wat soos 'n waaksame deurwag tot ons etiese bewussyn spreek.

\section{Jonker (1983) stel dit onomwonde:}

Die Skrif gee ons egter geen gronde om meer te sê as dat die heil slegs in Christus is nie, en dat dit die deel van die mens word slegs deur geloof in die Woord van God. Daarby moet ons bly.

(Jonker 1983:272)

Uit ' $n$ ekoteologiese hoek wil ons ook nie meer as dit sê nie. Die heil word egter nie bloot individualisties verstaan nie; dit sluit ook die heling van alle verhoudinge en die natuur in. Die Woord word ook nie as blote statiese begrip van afgehandeldheid verstaan nie, maar as dinamiese en lewende gebeurtenis met betrekking tot die God van die Woord.

Die verhouding met die God van die toekoms - die Heer wat kom - word weerspieël in die onpeilbare aard van ons bestaan; iets van sy immanente teenwoordigheid in die wete dat ons in sý kosmos (huis) woon en werk. Ook as ons uit die tradisie van getuienis die vraag oor wie óns is in die vraag oor wie Hý is, hoor eggo, ontdek ons iets van die teenwoordigheid van sy Gees wat deur ons werk.

Moltmann (2000:310-315) beskryf in hierdie sin God se geskiedenis met die wêreld as ' $n$ Trinitariese geskiedenis. Probeer ons dan uit hierdie tradisie van getuienis iets oor die aard van die mens sê, kan ons slegs maar antwoord op grond van ons ontmoeting met hierdie Een wat gestuur is, by ons bly, en weer sal kom. Dít doen ons met 'n diepe besef dat wat ons getuig, ook onder ons eie gebrokenheid gebuk gaan. Tog kan ons nie anders as om rekenskap te probeer gee van dít wat aan ons toevertrou is nie - veral in antwoord op die smagting en vrae van ons tyd.

In hierdie ekoteologiese ruimte kan etiese besluitneming nie tot vrae en antwoorde oor dit wat reg en verkeerd is, of tot blote huisreëls verskraal word nie. Die geskiedenis het getoon dat die mens nie aan vindingrykheid tekortskiet om reëls en wette te omseil, en dan in die tuin vir die gevolge te gaan wegkruip nie. Daarom moet daar ander soort vrae na vore kom indien ons uit 'n ekoteologiese hoek etiese besluite wil neem. Uit so 'n hoek kan ons nie by blote vrae oor die onmiddellike werklikheid bly nie.

Christelik-etiese besluitneming op grond van 'n ekoteologiese bewustheid van die relasionele aard van die mens se bestaan, kan prakties binne die breë parameters van die volgende riglyne geskied. Hierdie riglyne word nie as absolute waarhede aangebied wat oor tyd en ruimte strek, en alle mense en alle omstandighede geld nie. Dit kan egter wél as hulpmiddel vir die Christengelowige dien wat opreg, te midde van die etiese uitdagings van stamselnavorsing en -terapie, etiese besluite moet neem en uitvoer. Hierdie riglyne sal Christengelowiges help om nie bloot op veralgemening, opvattings, opinies of wette te vertrou nie, maar in elke situasie oor die moontlike hantering van morele dilemmas te besin.

\section{Bedoeling en motief}

Tradisioneel is daar volgens ' $n$ ontologiese benadering gevra: 'Wat is die universele beginsel of reël?' Aan die ander kant het diegene met ' $n$ utilitaristiese benadering gevra: 'Wat is die gevolge?' Hierdie tipe vrae het wél waarde, maar lei meer dikwels tot uiterste, onversoenbare standpunte, wat op hul beurt tot ongebalanseerde besinning en besluitneming lei, en in ' $n$ algehele stryd ontaard. Volgens die ekoteologiese perspektief word die motief of bedoeling agter besluitneming en optrede eerder bevraagteken. 'n Vraag soos 'Hoekom doen ek dit?' of 'Wat is my bedoeling?' sou dus meer gebalanseerde besinning en besluitneming tot gevolg hê. Die relasioneel-antropologiese perspektiewe wat na vore gekom het, sou hierdie vraag dalk ook na 'n metavlak voer, naamlik 'Vír wie of áán wie doen ek dit?' (1 Kor 4:1-5; Heb 4:12-13).

\section{Maatskaplike verankering}

Maatskaplike, politieke en godsdienstige sensitiwiteit kan ons in ' $n$ ekoteologiese benadering tot ' $n$ dieper bewustheid van ons eie sosiale konstrukte, en die invloed wat dit op ons besluitneming het, lei. Vooronderstellings en aannames uit ons eie agtergrond en opvoeding word in 'n ekoteologiese benadering as ' $n$ gegewe aanvaar. Hierdie erkenning van ons eie maatskaplike, politieke en godsdienstige verankering kan ons tot insiggewende vrae lei, soos 'Watter maatskaplike, kulturele en godsdienstige vooronderstellings laat my só dink, voel of optree?'.

\section{Teologiese uitgangspunte en aannames}

Die brandpunte in die huidige teologiese debat kan in ' $n$ ekoteologiese benadering by ons ' $n$ bewustheid wek van die verskeidenheid moontlike beskouinge wat oënskynlik op dieselfde Skrif- en getuienistradisies gebou word. Ons kan die tydelikheid en voorlopigheid van ons eie perspektiewe en selfs teologiese teorieë erken. Hierdie perspektiewe kan ons ook intenser bewus maak van God se teenwoordigheid, en die belang van God se verhouding met ons. Dan sal ons ook noodwendig vra wat God se bedoeling is, wat God wil hê, en wat God wil doen.

\section{Verhoudinge}

Ekoteologies-antropologiese perspektiewe kan ons laat vrae vra oor ons verantwoordelikheid in die multidimensionele netwerk van verhoudinge waarin ons bestaan. Vrae wat uit hierdie hoek na vore kan kom, is 'Wat doen my optrede aan my verhouding met ander?', 'Wat getuig my optrede van my verhouding met ander?', 'Wat doen my optrede aan my verhouding met God?', 'Wat getuig my optrede van my verhouding met God?', 'Wat doen my optrede aan my verhouding met myself?', en 'Wat getuig my optrede van my verhouding met myself?'.

\section{Eskatologies}

Die ekoteologiese beskouinge van die eskatologiese grondslag van etiese optrede kan ons meer bewus maak van die motiverende krag wat verwagting en hoop ten opsigte van etiese besluitneming kan bied. Só sal ons dan vrae met betrekking tot die verlede, hede én toekoms formuleer - vrae soos 'Wat het God vir my gedoen?', 'Wat doen Hy elke dag vir my?', 'Wat het Hy belowe om te doen?', en 'Hoe antwoord ek op sy genade en liefde in Christus?'.

Bowenal, miskien lei hierdie ekoteologiese beskouing van die relasionele aard van menswees ons tot die belangrikste vraag: 'Maar julle,' het Hy gevra, 'wie, sê julle, is Ek?' (Matt 16:15).

\section{SAMEVATTENDE BESINNING}

Die nuwe biotegnologiese verband waarin IVF, die kartering van die menslike genoom, en stamselnavorsing en -terapie 'n werklikheid geword het, rig unieke uitdagings tot sowel die 
samelewing as die teologie. Hierdie werklikheid vereis dat ons oor die etiese vrae oor menslike lewe herbesin.

Die ontdekking van stamselle het nuwe insigte oor die fisiologie van die mens gebring, en daarmee saam beloftes van hoop vir die potensiële genesing van verskeie siektes. Die praktyk van stamselnavorsing, veral ten opsigte van navorsing oor embrioniese stamselle, bring ook die samelewing voor ernstige en komplekse etiese dilemmas te staan. Iewers tussen die uiterstes van oordrewe optimisme oor stamselnavorsing, en radikale verwerping daarvan, móét daar 'n gebalanseerde beskouing van hierdie praktyk wees.

Die debat in die politieke sfeer maak dit ook duidelik dat daar nog geen algemene konsensus oor wetgewing in dié verband bestaan nie. Christelik-etiese perspektiewe kan in ' $n$ ekoteologiese benadering ook sinvol tot die politieke debat en etiese vrae oor riglyne vir besluitneming bydra.

Die huidige teologiese debat bevat uiteenlopende standpunte van streng konserwatisme wat stamselnavorsing en terapie voor die voet as sonde veroordeel, tot totaal liberale en pragmatiese argumente wat stamselnavorsing en -terapie onvoorwaardelik aanvaar en as wonderkuur voorhou. Tussen hierdie uiterstes is daar egter ook stemme wat versigtiger oor die kompleksiteit van hierdie verskynsel dink en praat.

Die vraag na antropologiese herbesinning sal uit 'n ekoteologiese benadering ook die kosmologiese aspekte van relasionele bestaan moet verreken. In 'n eko-etiese besinning behoort die natuurlike en kosmiese aard van die menslike bestaan wat ruimte en tyd betref, 'n inklusiewe waardering vir die kompleksiteit van menslike denke, emosies en gedrag teweeg te bring.

'n Postfondamentalistiese uitgangspunt kan tot die transversale gesprek tussen die Christelike etiek, natuurwetenskap en biotegnologiese ontwikkeling bydra.

Die verbreding van morele narratiewe, en die waardering vir relasionele Christelik-antropologiese perspektiewe, dien as alternatief vir streng monolitiese begrippe van waarheid, objektiwiteit en rede.

'n Soeke na die aard van menslike waarde as intrinsieke eienskap in die gene sal vrugteloos wees. Uit 'n ekoteologiese hoek is die erkenning van menslike waarde 'n dinamiese gebeurtenis wat deur die verhouding met God in sy skepping plaasvind en daaruit spruit. Die mens moet dus in ' $\mathrm{n}$ bepaalde nis gewaardeer word. Waarde lê derhalwe opgesluit in die energie van hierdie verhouding, en nie in die materie van DNS nie.

Hieruit volg dat menslike waarde nie in ' $n$ bepaalde intrinsieke waarde setel nie, maar eerder in die lig van 'n sakramentele begrip van menslike lewe beskryf kan word. In hierdie sin setel 'n persoon se waarde in die 'deelwees' van die liggaam van Christus. Analogies met die koinonia by die Nagmaal, word die teenwoordigheid van Christus met betrekking tot die communio sanctorum verstaan. Die samesyn van sakramentele gemeenskap word só die anker vir menswaardigheid. Buitendag (2005:13-14) verwoord dié begrip tereg soos volg: 'Being human is not merely a genomic matter, but a sacramental experience. This is also the route of society's Christian identity.'

Die debat laat ons besef dat die wonder van menslike lewe ons noop om ons verstaanshorisonne te verbreed, om in ' $n$ relasionele begrip van menswees ook die bosintuiglike en selfs die onverklaarbare in te sluit. In hierdie studie het dit duidelik geblyk dat ' $n$ breër begrip van 'n relasioneel-antropologiese menslike bestaan tot nuwe perspektiewe in die transversale ruimte van interdissiplinêre debatvoering kan lei. Antropologiese herbesinning verreken uit 'n ekoteologiese benadering ook die kosmologiese aspekte van relasionele bestaan.
Die mens moet dus in sy geheel beskou word. Die hele mens, met sowel liggaamlike as geestelike kenmerke, in 'n netwerk van verhoudinge, is die eerste uitgangspunt vir ons begrip van die beeld van God. Hierdie perspektief verwoord stellig die basiese riglyn vir denke oor die aard, wese en waarde van die mens uit 'n ekoteologiese hoek. Die erkenning van die relasionele aard van die menslike bestaan ontsluit ander beskouinge van hoe die mens in verhouding tot God verstaan kan word.

\section{LITERATUURVERWYSINGS}

Andrews, P.J., Damjanov, I., Simon, D., Banting, G.S., Carlin, C., Dracopoli, N.C. \& Føgh, J., 1984, 'Pluripotent embryonal carcinoma clones derived from the human teratocarcinoma cell line Tera-2. Differentiation in vivo and in vitro', Laboratory Investigation: A Journal of Technical Methods and Pathology 50(2), 147-162, toegang verkry op 05 Februarie 2008, op http://www.ncbi.nlm.nih.gov/pubmed/6694356.

Atala, A., Thomson, J., Nerem, R. \& Lanza, R ., 2008, Principles of regenerative medicine, Academic Press, Cambridge.

Baier, P.C., Schindehutte, H.J., Thinane, K., Flugge, G., Fuchs, E., Mansouri, A., Paulus, W., Gruss, P. \& Trenwalder, C., 2004, 'Behavioural changes in unilaterally 6-Hydroxy-Dopamine lesioned rats after transplantation of differentiated mouse embryonic stem cells without morphological integration', Stem Cells 22, 396-404.

Barth, K., 1960, Die Lehre von der Versöhnung [Die leer van versoening], Die Kirchliche Dogmatik IV/1, Zollikon, Zürich.

Begon, M., Townsend, C.R. \& Harper, J.L., 2006, Ecology: From individuals to ecosystems, 4 e uitg., Blackwell Publishing Ltd., Malden.

Böhme, G., 2001, Ethics in context, Blackwell Publishers Inc., Malden.

Bratton, S.P., 1998, 'Penning the goring bull: Evaluating five potential Christian ethical responses to environmental pollution', in J.E. Carroll \& K. Warner (reds.), Ecology and religion: Scientists speak, pp. 111-133, Franciscan Press, Richmond, Indiana.

Browning, D., 2006, Christian ethics and the moral psychologies, Wm. B. Eerdmans Publishing Co., Cambridge.

Buitendag, J., 2004, 'Anders Dink Anders Doen. Op Soek na 'n Eko-teologiese Perspektief op Kloning', Verbum et Ecclesia 25(2), 1-23.

Buitendag, J., 2005, 'The Human Genome Project (HGP) as a case study in the debate about the relationship between theology and natural science', HTS Teologiese Studies/ Theological Studies 61(3), 753-769.

Buitendag, J., 1999, 'Wat is die mens!' in D.J.C Van Wyk (red.), 20ste eeu Hervormde Teologie, pp. 322-338, SENTIK, Pretoria.

Clark, G., 1973, Bakers dictionary of Christian ethics, in C.F.H. Henry (red.), Baker Book House, Grand Rapids.

Colman, A. \& Kind, A., 2000, 'Therapeutic cloning: Concepts and practicalities', Trends in Biotechnology 18(5), 192-196.

Davies, D.J., 2002, Anthropology and theology, Berg, Oxford.

Davila, J.C., Cezar, G.G., Thiede, M., Strom, S., Miki, T. \& Trosko, J., 2004, 'Use and application of stem cells in toxicology', Toxicology Science 79, 214-223.

Deane-Drummond, C.E., 2006, Eco-theology, Saint Mary's Press, Winona.

Deist, F., 1992, 'Ethics', in A concise dictionary of theological and related terms, Nasionale Boekdrukkery, Kaapstad.

De-Leon, S.B.T. \& Davidson, E.H., 2007, 'Gene regulation: Gene control network in development', Annual Review of Biophysics and Biomolecular Structure 36, 191-212.

Dombrink, J. \& Hillyard, D., 2007, Sin no more: From abortion to stem cells, understanding crime, law, and morality in America, NYU Press, New York.

Donovan, P.J. \& Gearhart, J., 2001, 'The end of the beginning for pluripotent stem cells', Nature 414, 92-97.

Dreyer, P.S., 1979, Hoofstrominge van sedeleer, HAUM Uitgewery, Pretoria.

Edwards, D., 2001, Earth revealing earth healing: Ecology and Christian theology, Liturgical Press, Collegeville. 
Engels, E.M., 2001, ‘Orientierung an der Natur? Zur Ethik der Mensch-Tier-Beziehung [Oriëntering ten opsigte van die natuur? Die etiek van die mens-dier verhoudingl', in $\mathrm{M}$. Schneider (red.), Den Tieren gerecht werden. Zur Ethik und Kultur der Mensch-Tier-Beziehung, pp. 68-87, Schweisfurthstigting, Universiteit van Kassel, Kassel.

Finnis, J., 2002, Some fundamental evils in generating human embrios by cloning, Anthony Rowe Ltd., Londen.

Floss, T. \& Wurst, W., 2002, 'Functional genomics by genetrapping in ES sells', in K. Turksen (red.), Embryonic stem cells: Methods and protocols, pp. 347-359, Humana press, New Jersey.

Harris, J., 2004, On cloning, Routledge Press, Londen.

Hauerwas, S., 1991, The teaceable kingdom: A primer in Christian ethics, Notre Dame Press, Indiana.

Heyns, J. \& Jonker, W., 1977, Op weg met die teologie, Nasionale Boekdrukkery, Kaapstad.

Holland, S., Lebacqz, K. \& Zolloth, L., 2001, The human embryonic stem cell debate: science, ethics, and public policy, MIT Press, Cambridge.

Jonker, W., 1983, Die gees van Christus, Nasionale Boekdrukkery, Kaapstad.

Kass, L. \& Wilson, J.Q., 1998, The ethics of human cloning, American Enterprise Institute, Washington.

Kochar, P.G., 2004, 'What are stem cells?', ProQuest Review Article (Cambridge Information Group) 1, 1-9, toegang verkry op 06 Maart 2008, op http://www.csa.com/discoveryguides/ stemcell/overview.php.

Koller, P., 2002, Human genome technology from the viewpoint of efficiency and justice, Anthony Rowe Ltd., Londen.

LaCugna, C.M., 1991, God for us: The trinity and Christian life, Harper, San Francisco.

Lanza, R.P., Cibelli, J.B. \& West, M.D., 1999, 'Human therapeutic cloning', Nature medicine 5, 975-977.

Le Roux, C.J.P., 1991, 'EKO-TEO-LOGIE', DD-proefskrif, Departement Dogmatiek en christelike etiek, Universiteit van Pretoria.

Lett, J., 1996, 'Scientific Anthropology', in D. Levinson \& M. Ember (red.), Encyclopedia of cultural anthropology, Henry Holt and Company, New York, pp. 1141-1148, toegang verkry op 06 September 2008, op http://faculty.irsc.edu/faculty/jlett/ Article\%20on\%20Scientific\%20Anthropology.htm

Mason, C. \& Dunnill, P., 2008, “The strong financial case for regenerative medicine and the regen industry. Advanced centre for biochemical engineering', Regenerative Medicine 3(3), 351-363.

Mazzoni, C., 2002, Ethics and law in biological research, Anthony Rowe Ltd., Londen.

McGrath, A.E., 1999 'Augustine on fallen human nature', in A. McGrath (red.), The Christian theology reader, p. 416 , Blackwell, Oxford.

Moltmann, J., 2000, Experiences in theology, SCM Press, Londen.

Moltmann, J., 2000, Theology of hope, SCM Press, Londen.

Monroe, K., Miller, R.B. \& Tobis, J.S., 2008, Fundamentals of the stem cell debate: The scientific, religious, ethical, and political issues, University of California Press, Berkeley.

North, R., 1995, Life on a modern planet: A manifesto for progress, Manchester University Press, Londen.

Nürnberger, K., 1975, Sistematiese teologie, Genadendalse Drukkery, Genadendal.

Odendal, F. \& Gouws, R., 2005, 'Etiek', in Verklarende handwoordeboek van die Afrikaanse taal, 5de uitg., Pearson, Kaapstad.
Ott, H., 1981 Die Antwort des Glaubens, Kreuz Verlag, Berlyn.

Pack-Brown, S. \& Braun Williams, C., 2003, Ethics in multicultural context, Sage Publications Inc., Thousand Oaks.

Panagiotis, A., 2004, 'Stem cells from differentiated cells', Molecular Interventions 4, 81-83.

Pannenberg, W., 1996, Theologie und Philosophie, Hubert \& Co., Göttingen.

Pannenberg, W., 2004, Anthropology in theological perspective, Continuum International Publishing Group, New York.

Peters, T., 2007, The stem cell debate, Fortress Press, Minneapolis.

Petit-Zeman, S., 2001, 'Regenerative medicine', Nature Biotechnology 19, 201-206, toegang verkry op g.d., op http:// www.nature.com/nbt/journal/v19/n3/abs/nbt0301_201. html.

Piazza, A., 2002, The Human Genome Project and the genetists responsibility, Anthony Rowe Ltd., Londen.

Pomeroy, B., 1999, Ancient Greece: A political social and cultural history, Oxford University Press US, New York.

Rao, M.S., Cai, J. \& Weiss, M.L., 2004, 'In search of "stemness"', Experimental Hematology 32, 585-598.

Ricoeur, P., 1992, Oneself as another, Chicago University Press, Chicago.

Sandal, M., 2007, The case against perfection, Harvard University Press, Londen.

Schöler, H.R., 2007, 'The potential of stem cells: An inventory', in N. Knoepffler, D. Schipanski \& S.L. Sorgner, Humanbiotechnology as social challenge, p. 28, Ashgate Publishing Ltd., Farnam UK.

Shapira, A., 2002, Biomedical law: The aims and limits of regulating biomedical science and technology, Anthony Rowe Ltd. Londen.

Siegel, G.J., 2008, 'Plato', Stanford encyclopedia of philosophy in Ethics of Stem Cell Research, toegang verkry op 07 Mei 2009, op http://plato.stanford.edu/entries/stem-cells/.

Siegel, G.J., Albers, R.W., Brady, S. \& Price, D.L., 2006, Basic neurochemistry: Molecular, cellular, and medical aspects, Academic Press, Oxford.

Simon, J., 2002, Human dignity as regulative instrument for human genome research, Anthony Rowe Ltd., Londen.

Solo, P. \& Pressberg, G., 2007, The promise and politics of stem cell research, Greenwood Publishing Group, Santa Barbara.

Stedman, T.L., 2000, 'Stemcells' in B. Pugh \& M. Lippincott (reds.), Stedman's medical dictionary, , vol. 17, 27ste uitg., pp. 84-93, Williams \& Wilkins, Baltimore.

Suid-Afrika, 2003, Nasionale gesondheidswet, Staatsdrukker, Pretoria.

Tallacchini, M., 2002, The epistemic state -The legal regulation of science, Anthony Rowe Ltd., Londen.

Thomas, P., Dyck, P.J. \& Kynaston, P., 1999, Diabetic neuropathy, WB Saunders, Michigan.

Thomson, J.A., Itskovitz-Eldor, J., Shapiro, S.S., Waknitz, M.A. Swiergiel, J.J., Marshall, V.S. \& Jones, J.M., 1998, 'Embryonic stem cell lines derived from human blastocysts', Science 282(5391), 1145-1147.

Till, J.E. \& McCulloch, E.A., 1961, 'A direct measurement of the radiation sensitivity of normal mouse bone marrow cells', Radiation Research 14, 2213-2222.

Weber, M., Baehr, P.R. \& Wells, G.C., 2002, The protestant ethic and 'The spirit of capitalism', Penguin Classics, Londen.

Wolf, E.R., 1964, Anthropology, Prentice-Hall, New Jersey.

Wyschogrod, E. \& McKenny, G. 2003, The ethical, Blackwell Publishing Ltd., Malden.

Zheng, X., Cai, J., Chen, J., Luo, Y., Zhi-Bing, Y., Fotter, E., Wang, Y., Harvey, B., Miura, T., Backman, C., Chen, G.J., Rao, M.S. \& Freed, W.J., 2004, 'Dopaminergic Differentiation of Human Embryonic Stem Cells', Stem Cells 22, 925-940. 